\title{
The Comparative Analysis of the Factors Effecting Brand Loyalty towards Samsung Products
}

\author{
Muhammad Ramiz \\ Department of Management Sciences, The Islamia University of Bahawalpur (Pakistan) \\ Muhammad Qasim \\ Department of Management Sciences, The Islamia University of Bahawalpur (Pakistan) \\ Muhammad Rizwan (Corresponding author) \\ Lecturer, Department of Management Sciences, \\ The Islamia University of Bahawalpur, Pakistan \\ E-mail: rizwan.arshad@iub.edu.pk
}

\section{Faizan Aslam}

Department of Management Sciences, The Islamia University of Bahawalpur (Pakistan)

\section{Ammar Khurshid}

Department of Management Sciences, The Islamia University of Bahawalpur (Pakistan)

$$
\text { Doi:10.5296/ jsr.v5i1.6569 URL: http://dx.doi.org/10.5296/ jsr.v5i1.6569 }
$$

\begin{abstract}
Two conditions consistency levels of purchase for specific brand over the span of time imply on brand loyalty. The most precious asset of an organization as there is neck to neck competition in the market and it is essential for the survival of companies. Aims of this research are basically to spot what kinds of factors influence brand loyalty in Pakistan. Six preceding factors influence the consumer's brand loyalty. By using self-administered questionnaires we collected data from our 152 respondents. For regression analysis we entered all that that data into SPSS and do analysis also. Results of our study show significant relationship of brand image, brand trust, customer satisfaction, perceived quality, purchase
\end{abstract}


criteria and advertising spending on brand loyalty. These factors influence the green purchase intention. Our study is a vital source for the national and international marketers to collect information how different factors effect consumer's brand loyalty.

Keywords: brand loyalty, brand image, brand trust, customer satisfaction, perceived quality, purchase criteria and advertising.

\section{Introduction}

Brand loyalty is the level by which consumers continue to purchase the same brand within a product or service category. "The unfair behavioral reactions, expressed over time, out of a set of such brands, and is a function of emotional (decision making, evaluative) processes by some assessment of making elements, with respect to one of more alternate brands." Brand loyalty defines the consumers are willingness to pay high prices to a definite brand in the same manufactured goods faction and direct people around him to purchase that product (Glidden's, 2002).

The improved sales and the capability to charge premium prices are the effect of brand loyalty. In other words, brand loyalty can be considered as the extent to which a customer makes repeated purchase. Many factors influence brand loyalty and it is a complex process. The purpose of our research is to investigate the factors affecting the brand loyalty specifically perceived quality, brand image, brand trust, purchase criteria, advertising spending and customer satisfaction.

Coming on top of the list is the brand image or the identity of the brand plays a very important role in differentiating a brand from its competitors and helps building up new costumers as the studies has shows that in the wide variety of brand the customers choose the most prominent and oldest ones as they have strong brand image but it take trust to build up the image of the brand.

The perceived quality is also among the most vital factors that influence the most. It is the customer's observation about the general quality and the supremacy of the product or service in term of its basic purpose virtual to available substitutes is perceived quality. Perceived quality cannot essentially be independently determined, in part because it is a perception and also involves the judgments about what is important to customers. Perceived quality could be considered as the intangible feelings about a brand. Nevertheless, perceived quality is based on essential dimensions that include uniqueness of the goods by which the brand is fond of such as dependability and performance. It will be useful to identify and measure the underlying dimensions to understand perceived quality,

Business starts and close for the customer and hence their satisfaction and dissatisfaction matters much for running the business. Customer satisfaction is a part of customer's knowledge that shows a supplier's behavior on customer's expectation. It can only be attained through overall good relationship between the customer and supplier. Satisfaction has positively influence on brand trust. If the product meets the consumers desire it means product reaches its satisfaction level. And this level enforces the consumer to revisit the same brand again and again. An understanding of the impact of brand image, perceived quality and 
satisfaction towards the indirect effects of advertising on brand loyalty will help managers seize the true impact of advertising in development of brand loyalty. Advertising spending has also positively influence on making brand trust. Price promotion was considered as company's offensive strategy for attracting the new customers even from the rival brands but advertising spend has been considered as the company's defensive strategy for retaining its customer loyalty stated by Agrawal (1996).

On the other hand purchase criteria pave the way towards brand loyalty. It consists of the standards over which the product is evaluated by its prospective purchaser. These principles might relay to a product in terms of its trustworthiness, expertise, sale's person's credibility, technical specifications, and the manufacturer of the product in terms of its reputation for quality.

\section{Literature review}

\section{Brand loyalty}

Brand loyalty is the extent to which the customer recommends and keeps on purchasing the same product/service. As per (Aaker 1992) it implies both favorable attitude and steady purchase of the same brand. As proposed by (Jacoby and Olson (1970)) it was a emotional purchase practice formed by some definite decision units who measured more than one brands.

Guest $(1942,44,55,64)$ defined brand loyalty as an attitude behavior and a measured degree of preference consistency and purchasing behavior. Brand loyalties develop when the brand fits the brand image or personality of the customer or when brand offers satisfying and distinctive profit that consumer seeks. In both instances individual affection develops towards a brand.

In early studies, researchers usually include the repurchase for measuring the brand loyalty. But in recent studies, some investigators indicated that for the measurement of brand loyalty the most suitable way is to measure the affective loyalty.

Assessment of the literature showed that there are two separate approaches for investigating brand loyalty. One estimates the direct effect of several determinants on brand loyalty. For example, Yoo et al. (2000) investigated the mixed marketing factors over the brand loyalty. The other approach concentrates on the indirect effects of these determinants on brand loyalty like advertising spending affects potential of product or service quality (Kirmani and Wright, 1989; Moorthy and Zhao, 2000; Yoo et al., 2000), its role is in some ways connected to brand loyalty signifying that rather than the advertisement itself, it is how advertising affects customer perception of the firm that is more critical in shaping brand loyalty.

\section{Customer satisfaction}

By using a specific product satisfaction is the consumer's positive attitude developed in the result of his depletion understanding. Customer satisfaction is the originator of the brand loyalty it. As (Kasmer, 2005) customer satisfaction is the assessment about the brand. All the key factors regarding Brand loyalty effecting their judgment of repeated purchase. According 
to (Labarbera and Mazursky, 1983)the satisfaction is found to be increased when computing the brand loyalty in terms of repeated purchase of the same product. Satisfaction is commonly considered in many studies (Lam, et al, 2004; Tian, 1998; Yang, 2004; Li and Vogel song, 2003) indicate that the rapid judgment of the customers experience results the satisfaction, the satisfaction is found to be the crucial helping element while predicting the customer satisfaction (Rizwan et al., 2013).

We concluded from the studies that loyalty is affected by satisfaction and social variables, tha are estimates of repurchase intention for products are predicted by satisfaction (Egret, A. \&Ulaga, 2002).. Rodriguez del Bosque and San Martin (2008) said that consumer satisfaction is not only rational but also emotional. While in the definition of satisfaction, there are at least two common formulations of satisfaction: transaction- specific and overall satisfaction. Transaction-specific satisfaction is an instant post-purchase evaluative judgment and, as such, is an affective reaction to the most recent experience with a firm (Oliver,1993). According to transactional specific approach that contentment happens at the post-consumption stage following a single encounter with the service provider (e.g., satisfaction with a specific employee) (Jones \& Suh 2000). According to (e.g. Ismail, Hasnah, Ibrahim, \& Isa, 2006; Da Silva \& Syed Alwi , 2006; Anderson \& Sullivan, 1993; Chiou et al., 2002; Bloemer \& Ruyter, 1998: Yang \& Peterson, 2004)several studies confirmed that consumer's satisfaction has positivelypartial loyalty. When customers are happy and satisfy from branded products then they also tell others to purchase them. They are less likely to shift to other different brand, and are likely to repeat purchase said (Bennett \& Rundle-Thiele, 2004).

\section{H-1 satisfaction has positive effect over brand loyalty}

Perceived quality states the customer's observation of the overall superiority of a product or service with respect the satisfaction of its purpose, effective to alternatives. Basically the features and the characteristics are to fulfill the promised needs are encompassed by the quality. According to (Olsen, 2002)Perceived quality is the common estimation of a customer about the product or brand quality, its consistency to the values and it's gratifying its functions.

We can say it is "a deeply held assurance to re-buy a preferred product reliably in the future. There is a positive relationship between brand loyalty and perceived as the studies of (Chiang, 1991; McConnell, 1968). Such type of a relationship has the potential to contribute differentially to customer outlooks and behaviors, because the strength of brand loyalty could be explained by perceived quality (McConnell, 1968).

The regarded effects of apparent quality over brand loyalty are direct and indirect. Perceived quality is basically a virtual concept and changes liable on the experiences and potentials of people. As Oliver (1999) said that perceived quality is perceptive and leads overall satisfaction, which is an effective response. Perceived quality also affects the trust in positive sense that more indicate to brand loyalty as per the former research by Corritore et al., (2003) investigated the effect of perceived quality on trust. 


\section{H-2 perceived quality positively influence the brand loyalty and customer satisfaction}

\section{Brand image}

Brand plays a very important role in discriminating a brand from its opponents and helps making up new costumers. A brand's image is an essential factor of brand equity, (Aaker, 1991). Keller (1993) and shows differently the brand image, brand suggestions in addition to the favorability, might and exclusivity of these connotations. By keeping in view an image is emotionally constructed by the consumers few basic impressions selected from the lake of many Brands; it came into existence through an artistic course of action where the chosen impressions are expanded, inflated, and prepared.

In making consumers release the likelihood of purchase of that brand will increase which flourish that they need it and make its variance identity form its opponents.

By the public corporation or its manufactured goods which continuously holds a promising image, definitely increase a better position in the market, increase market share, workable competitive advantage, and or enactment (Park, Jaworski,\&MacInnis, 1986). Even that numerous empirical findings established that a promising image (i.e. Brand, store/retail) will lead to loyalty (e.g. Koo, 2003; Kandampully \& Suhartanto, 2000;).

The brand image is directly related to the brand loyalty due to the assistances the consumers feels they have from the brand. Keller (1993) defined that such type of image advantages can be grouped into experimental, useful, and demonstrative benefits, that were actually resulted from the study of Park et al. (1986). Here, we said that the practical advantages are linked to the intrinsic advantages of product or services utilization. For example, observed advantages refer to "kinds of feelings by using the product or services and usually communicate the product related qualities", whereasthe underlying needs for social approval or personal appearance and outer-directed sense of worth and basically correspond to non-product related attributes connected with figurative benefits.

\section{H-3 brand image have positive effect over the brand loyalty}

\section{Advertising spending}

Huge researches focuses on advertising as an ancestor of brand loyalty (Agrawal, 1996; Yoo et al., 2000). It has very important effect in reconstruction of supposed performance and usage experience of a particular brand (Kirmani and Wright, 1989; Moorthy and Hawkins, 2005). Since we are paying attention on the customer viewpoint we follow Kirmani and Wright's (1989) and adapt Yoo et al.'s (2000) conceptualization for defining advertising spending as the perceived frequency and expenditures as the measure of consumers perception on advertising spending..

Advertising spending plays important role in building up customers brand loyalty since it have no direct effect over it. Store image is related to advertising spending. Even after accounting for intended quality and price perceived quality and advertising spending are 
positively related. High brand equity is dependent on high promotional spending and store image. Consumer gladness (e.g. pleasantness and satisfaction) is prejudiced by their previous assessments. For example, if previous experiences from product (or quality) are pleasurable, the upcoming experience will be even better in inducing the same level of satisfaction.

The advertising can be considered as a "defensive" policy that build brand loyalty, that helps in retaining the brand loyal customers, and price promotions is considered as an "offensive" policy used to attract the customers from the rival brand. The weaker brand poses little threat on the strong brands and so they need to spend less for advertising. Instead of advertising they focus on promotional campaigns (provided advertising is cost effective) for attracting the weaker brand's loyal customers of the competing brand. But on the other hand the weaker brand had to spend on advertising for defending its market shares or retaining its existing customers, as promotions do not help much due to the difficulty in attracting away the stronger brand's loyal consumers. For protection of loyal customers from the rival brands the advertising spending is necessary. The only difference is that the weaker brand spends more while the stronger brands spend less on advertising.

\section{H-4 advertising spending positively influences the brand loyalty and brand image}

\section{Purchasing criteria}

The attainment of customer loyalty is the most optimistic outcome as a result of customer satisfaction. The concept of "loyalty" raised up of the term "persistence" coined by Copeland (1923). The stage of consumer's attitudes toward the demand, Persistence is for branded products. Consumers do not accept alternatives when they decide to purchase a product or service. Basically the concept of brand loyalty is widely checked in buyer and marketing studies as a performance, an attitude, or a composite of both these concepts. According to (Jacoby and Kyner, 1973), Brand loyalty studies showing that there are variances in purchasing criteria among brand loyalty.

A purchase criterion has been broadly in the literature as a forecaster of ensuing purchasing. Aaker and Keller (1990) stated thata brand with high consciousness and good image can promote brand loyalty to consumers, hence the higher the brand awareness the higher brand trust and purchase objective are to consumers. A well-known brand will have a higher purchase intention than a less well-known brand, Brand loyalty is a repurchase commitment that promises consumers will repurchase their, fortunate brands in the future and they will not change their loyalty under any situation.

Griffin (1997) stated that loyalty and the purchase cycle by representing the repurchase loop. When consumers purchase a product that they are not loyal to, they will purchase a different brand of that product. Hence the loyal consumer have a tendency to purchase the same brand that they feel a strong bond with and as long as this bond is not affected by switching factors (Dick and Basu, 1994; Bolton et al., 2000). According to Ehrenberg (1988) states that loyalty and switching factors do not mark the purchase choice instead it only be subject to on buyer characteristics. Johnson (1984), on the other hand, calls the decline of brand loyalty a myth, as neither Ehrenberg et al. (2004) nor Lal and Padmanabhan (1995) have found adequate 
evidence to prove else. It clearly seems that ambiguity among researchers about the impact of behavioral intentions and contextual factors on purchase decisions. Hence, the study aims to discover how all these factors (contextual factors, brand loyalty and brand switching) combined affect the purchase choices of buyers.

\section{H-5 purchase criteria positively influence the brand loyalty}

\section{Brand trust}

The motivation of standard consumer to rely on the qualifications of the brand to accomplish its stated purpose is called Brand trust (Moormal et al 1993, p. 315). This definition spans the two general approaches to trust in the literature (Dwyer and Lag ace., 1986). Firstly the trust is considered as the certainty, emotions and the partner's expertise; reliabilities resulted from anticipation about an exchange partner's worthiness. Secondly the trust is the behavioral intention reflected from confidence on a partner and weakness and doubt about the trustee (Moormal et al 1993, p. 315). Believing in the dependability and the honesty of one side to the other build up the trust (Moorman et al., 1992). The consumer's faith that the brand will accomplish certain purposes could be considered as brand trust. The factors like competence, compassion and honesty are qualified as the factors that indicate the characteristics of brand trust by Suh and Han (2003). Trust is the most important determinant of brand loyalty as it creates relation between the brand and customers stated by (Morgan and Hunt, 1994).Trust is determined as the predictor of loyalty in many literature studies.andif it is established the customer will be satisfied (Chaudhuri and Holbrook, 2001). Trust is stated very important for satisfaction by Berry (2000). As per (Morgan and Hunt 1994, The exchange relations created by trust are highly valued as the brand trust leads to brand loyalty or commitment Chaudhuri and Holbrook, 2001). The enduring desire to maintain a valued relationship is defined as the commitment by (Moorman, Zaltman, and Deshpande 1992, p. 316). Thus, it could be concluded that both purchase and attitudinal loyalty are given by the trust. Trusted brands should be purchased more often and should evoke a higher degree of attitudinal commitment.

\section{H-6 brand trust has positive effect over brand loyalty and purchasing criteria}

\section{Research Methodology:}

The current research is descriptive in its nature. Descriptive research can be explained as describing something, some phenomenon or any particular situation. Descriptive researches are those researches that describe the existing situation instead of interpreting and making judgments (Creswell, 1994). The main objective of the descriptive research is verification of the developed hypothesis that reflects the current situation. This type of research provides information about the current scenario and focus on past or present for example quality of life in a community or customer attitudes towards any marketing activities (Kumar, 2005). 


\section{Macrothink}

\subsection{Sample Data:}

In order to collect the data for understanding the situation about the purchase intentions the same brand/product, a sample of 150 respondents were asked to participate in a self-administered questionnaire. The population for the current research is consumer in Pakistan. The current study utilizes a nonprobability sampling technique that is convenience sampling. Convenience sampling is a sampling technique that obtains and collects the relevant information from the sample or the unit of the study that are conveniently available (Zikmund, 1997). Convenience sampling is normally used for collecting a large number of completed surveys speedily and with economy (Lym et al, 2010).

It is ensured that the sample members possess two main qualifications to participate in the self-administered survey. First, the sample members should have enough knowledge about Brand loyalty; secondly, they have a regular purchasing pattern of buying some branded products, it definitely influences the attitude and behavior of the respondent.

\subsection{Instruments and Measures:}

The survey instrument of the current study address two major purposes: First is to analyze the relationship of different variables in the adoption of Brand loyalty. Second, to collect information about the different characteristics of the respondents that can be used to understand the variations in different categories.

The survey instrument contains two sections. Section 1 includes different personae and demographic variables. This section will obtain the respondent's information about gender, age, income and education.

Section 2 includes the latent variables that are important in the current study. These variables includeBrand loyalty, Brand image, Brand trust, Customer satisfaction, Perceived quality, Purchase criteria and Advertising spending. This section of study is developed based on the past literature and already used questionnaires. The scales of the study were adopted from the previous literature and published studies. The first variable of the study is the Brand loyalty having eight items from the study of The next variable brand image with 5 items that was taken from the study of Swaitand Sweeney (2000). The next variable brand trust having five items from the study of Matzler it al, (2008). Chanduhuri and Holbrook,(2001). The next variable is the customer satisfaction with 2 items referring Ragunathan and Irwin(2001). After that the study includes perceived quality with three items from Hyoja-dong and Chuncheon (9 march 2012). Next variable is purchase criteria having four items taken from the study of JungmiOh, Susan S.Fiorito(2002).the last variable is the advertising spending with four items of Hong-Youl Ha, Joby John (2011) study. 
Table 1: $\quad$ Scales of the Study

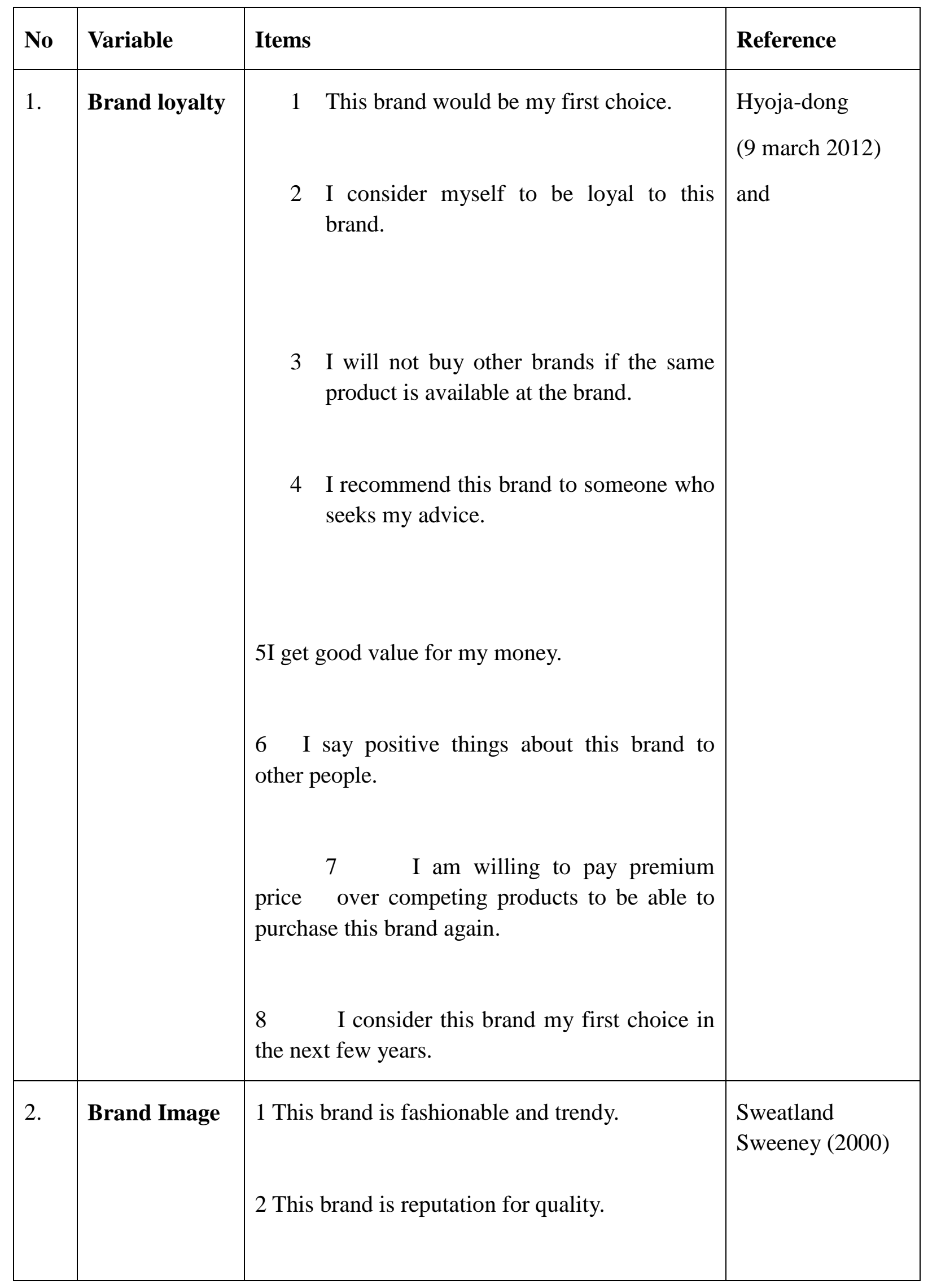




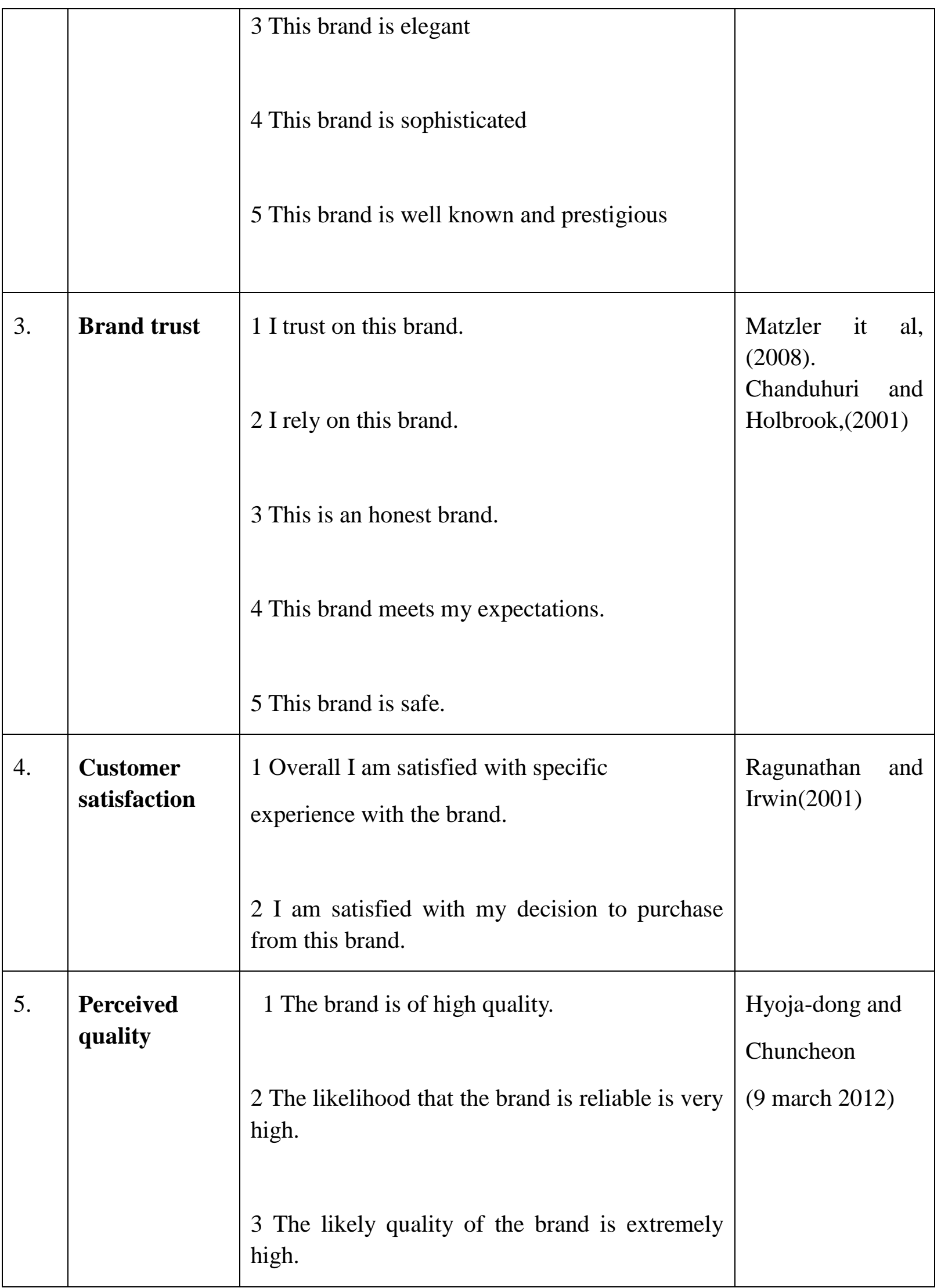




\begin{tabular}{|c|c|c|c|}
\hline 6 & $\begin{array}{l}\text { Purchase } \\
\text { criteria }\end{array}$ & $\begin{array}{l}1 \text { You buy this brand due to your status } \\
2 \text { You buy this brand as it seems fashionable } \\
3 \text { You buy this brand due to high awareness } \\
4 \text { You buy this due to its attractiveness }\end{array}$ & $\begin{array}{l}\text { Jungmi Oh, } \\
\text { Susan S. } \\
\text { Fiorito } \\
\text { (2002) }\end{array}$ \\
\hline 7 & $\begin{array}{l}\text { Advertising } \\
\text { spending }\end{array}$ & $\begin{array}{l}1 \text { The ads for Samsung are frequently seen } \\
2 \text { The ads of Samsung seems more expensive } \\
\text { compared to the ads of competing brands }\end{array}$ & $\begin{array}{l}\text { Hong-Youl Ha, } \\
\text { Joby John } \\
\text { (2011) }\end{array}$ \\
\hline
\end{tabular}

\subsection{Procedure}

The questionnaire was distributed among 152 respondents in Bahawalpur city of Pakistan. These respondents are selected based on the criteria above mentioned. Before giving the questionnaire, the purpose of the study and questions were explained to the respondents so they can easily fill the questionnaire with relevant responses. A total of 152 questionnaires selected. After collecting, the completed questionnaires were coded and entered into SPSS sheet for further analysis.

\subsection{Reliability Analysis}

\begin{tabular}{|l|l|l|}
\hline Scales & Items & Cronbach Alpha \\
\hline Brand image & 5 & 0.811 \\
\hline Brand trust & 5 & 0.587 \\
\hline Customer satisfaction & 2 & 0.878 \\
\hline Perceived quality & 3 & 0.873 \\
\hline Purchase criteria & 4 & 0.827 \\
\hline
\end{tabular}




\section{Results and Analysis.}

\subsection{Profile of the Respondents}

Personal and demographic information of the respondents is presented in the following table.

\begin{tabular}{|c|c|c|c|}
\hline Variable & Category & Frequency & Percentage \\
\hline \multirow[t]{2}{*}{ Gender } & Male & 142 & 93.4 \\
\hline & Female & 10 & 6.6 \\
\hline \multirow[t]{6}{*}{ Age } & $15-20$ years & 35 & 23 \\
\hline & 20-25 years & 112 & 73.7 \\
\hline & $25-30$ years & 3 & 2 \\
\hline & $30-35$ years & & \\
\hline & $35-40$ years & & \\
\hline & Above 40 years & 2 & 1.3 \\
\hline \multirow[t]{6}{*}{ Income } & Below 15000 & 107 & 70.4 \\
\hline & $15000-25000$ & 19 & 12.5 \\
\hline & $25000-35000$ & 13 & 8.6 \\
\hline & $35000-45000$ & 4 & 2.6 \\
\hline & $45000-55000$ & 1 & 0.7 \\
\hline & Above 55000 & 8 & 5.3 \\
\hline \multirow[t]{3}{*}{ Education } & Matriculation & 2 & 1.3 \\
\hline & Inter & 8 & 5.3 \\
\hline & Bachelor & 116 & 76.3 \\
\hline
\end{tabular}




\begin{tabular}{|l|l|l|l|}
\hline & Master & 18 & 11.8 \\
MS/M. Phil & 7 & 4.6 \\
& PHD & 1 & 0.7 \\
\hline
\end{tabular}

\subsection{Hypothesis Testing}

This section of the study finally tests the model after satisfying the requirements of reliability and validity. The casual relationships of the independent variable were measured on dependent variables.

\subsubsection{Brand image and Brand loyalty}

According to the results of this study. The variable of Brand image has a significant positive relationship with Brand loyalty. Specifically, this variable has a significant positive relationship with $($ Beta $=.189)$ and $(\mathrm{p}=0.006)$. That means the Green purchase attitude more than $18 \%$ to green purchase intention. Results of the current study validate the H1.

\subsubsection{Brand trust and Brand loyalty}

The regression results of the study confirm the significant positive relationship between brand trust and brand loyalty with $($ Beta $=.413)$ and $(\mathrm{p}=0.000)$. According to these results, Brand trust value contributes more than $41 \%$ to Brand loyalty. Thus validating the results of $\mathrm{H} 2$.

\subsubsection{Customer satisfaction and Brand loyalty}

Regression analysis of the brand loyalty model shows that there is a significant positive relationship with $(\operatorname{Beta}=.122)$ and $(\mathrm{p}=0.008)$. The results suggest that the customer satisfaction is having more than $12 \%$ effect on Brand loyalty. Thus the results of the study support $\mathrm{H} 3$.

\subsubsection{Perceived quality and Brand loyalty}

The regression results of the study confirm the significant positive relationship between the Perceived quality and the Brand loyalty with $($ Beta $=.127)$ and $(\mathrm{p}=0.001)$. According to these results, Perceived quality is having more than $12 \%$ effect on Brand loyalty. The result of the study support H4.

\subsubsection{Purchase criteria and Brand loyalty}

The regression results of the study confirm the significant positive relationship between purchase criteria and brand loyalty with $(B e t a=0.124)$ and $(p=0.026)$. According to these results, Purchase criteria have more than $12 \%$ effect over the Brand loyalty. Showing the results of the study supports $\mathrm{H} 5$.

\subsubsection{Advertising spending and Brand loyalty}




\section{Macrothink}

The regression results of the study confirm the significant positive relationship between advertising spending and brand loyalty with $(B e t a=0.127)$ and $(\mathrm{p}=0.001)$. According to these results of the study the H6 is supported.

\subsubsection{Advertising spending and brand image}

The regression results of the study confirm the significant positive relationship between advertising spending and brand image with $(B e t a=0.453)$ and $(\mathrm{p}=.000)$. According to these results, advertising spending has more than $45 \%$ effect over the brand image. Showing the results of the study supports $\mathrm{H} 7$.

\subsubsection{Brand trust and purchase criteria}

The regression results of the study confirm the significant positive relationship between brand trust and purchase criteria with $($ Beta $=.545)$ and $(\mathrm{p}=.000)$. According to these results, brand trust has more than 54\% effect over the purchase criteria. Showing the results of the study supports H8.

\subsubsection{Perceived quality and customer satisfaction}

According to the results of this study. The variable of perceived quality has a significant positive relationship with customer satisfaction. Specifically, this variable has a significant positive relationship with $(\mathrm{Beta}=.623)$ and $(\mathrm{p}=0.000)$. That means the perceived quality is more than $18 \%$ to green customer satisfaction. Results of the current study validate the H9.

Table: Regression Results

\begin{tabular}{|c|c|c|c|c|c|c|}
\hline Hypothesis & Model Variables & $\begin{array}{l}\text { Est } \\
\text { im } \\
\text { ate }\end{array}$ & S.E. & C.R. & $\mathbf{P}$ & Results \\
\hline H1 & $\underset{\mathrm{BL}}{\mathrm{BI}}$ & $\begin{array}{l}.09 \\
6\end{array}$ & .082 & 1.966 & .006 & supported \\
\hline H2 & $\mathrm{BL}^{\mathrm{BT}} \longrightarrow$ & $\begin{array}{l}.37 \\
2\end{array}$ & .077 & 4.814 & .000 & supported \\
\hline H3 & $\mathrm{CS} \longrightarrow \mathrm{BL}$ & $\begin{array}{l}.11 \\
6\end{array}$ & .072 & 1.617 & .008 & supported \\
\hline H4 & $\begin{array}{l}\mathrm{PQ} \longrightarrow \\
\mathrm{BL}\end{array}$ & $\begin{array}{l}-.02 \\
2\end{array}$ & .055 & 2.398 & .001 & supported \\
\hline H5 & $\mathrm{PC} \longrightarrow$ & .14 & .064 & 2.188 & .030 & supported \\
\hline
\end{tabular}




\begin{tabular}{|c|c|c|c|c|c|c|}
\hline & BL & 0 & & & & \\
\hline H6 & $\begin{array}{l}\text { AS } \\
\text { BL }\end{array}$ & $\begin{array}{l}.11 \\
9\end{array}$ & .071 & 1.674 & .026 & supported \\
\hline H7 & ${ }_{\text {BI }}^{A S}$ & $\begin{array}{l}.05 \\
6\end{array}$ & .453 & 6.198 & .000 & supported \\
\hline H8 & ${ }_{\mathrm{PC}} \stackrel{\mathrm{BT}}{\longrightarrow}$ & $\begin{array}{l}.06 \\
5\end{array}$ & .545 & 7.971 & .000 & supported \\
\hline H9 & $\begin{array}{l}\mathrm{PQ} \\
\mathrm{CS}\end{array}$ & $\begin{array}{l}.07 \\
5\end{array}$ & .623 & 9.760 & 0.000 & supported \\
\hline
\end{tabular}

\section{Discussion}

The study purposed to identify the customers brand loyalty towards the cell phone brands specifically here in Samsung phones. To fulfill the purpose a research the factor that suited the conditions of the country were selected and applied over the (Samsung) company. To find out the extent to which each of them affects the customers brand loyalty towards the Samsung brand. Six brand loyalty factors that are Brand image, brand trust, perceived quality, customer satisfaction, purchase criteria and advertising spending.

Apart from the effect of these factors over brand loyalty, this study is also aimed to highlight their effects on each other, for this purpose the effects of advertising spending over the brand image, brand trust over purchase criteria and perceived quality over customer satisfaction are noted.

Over all we find the support for all the hypotheses in our proposed model. But the brand trust seems to play more important role over the brand loyal then other variables. As shown by the statistical analysis results brand trust is important factor in the development of brand loyalty. The effect of brand trust on brand loyalty was found to be significant $(B=.413)$, hence supporting H2, the result is also consistent with (Moorman, et.al, 1992), Morgan and Hunt, 1994.Brand loyalty could be achieved through brand trust by the creation of high value exchange relationship with the customer where he could be committed to the brand and could share his preferences. On the other hand the investigation of brand trust effect influence over the purchase criteria have also shown positive results since it was found significant by () showing the brand trust influential over the characteristics they have for their product of choice.

Brand image is the separate identification of brand in the presence of competitors in the mind of the customer, hence it is also one of the major factors allowing the customer to purchase a brand and be consistent with it. In our study the brand image is the second variable effect the brand loyalty the most with the significance of $(B=.189)$ thus supporting $\mathrm{H} 1$, the results are 
also supporting Vazquez-Carrasco and Foxall (2006).

A satisfied customer is most likely to purchase the product of the same brand lead to the repeat purchase that builds up the brand loyalty. In this case the customers are satisfied with the benefit they gain from the product in terms of the price they paid to by the Samsung phone. This relationship of customer satisfaction and brand loyalty is shown by the statistical results obtained showing the significance $(B=.173)$, thus supporting the study of Ismail, Hasnah, Ibrahim and Isa (2006). And confirming the H3.

Perceived quality in this case is measured in terms of the high quality and reliability of the brand as these two are the core reasons that when met the customer become loyal with the brand, and this relation is positive as shown by the results it have significance of $(B=.122)$ confirming the H4 and supporting the study of (McConnell, 1968). The perceived quality also influence the customer satisfaction positively as shown by the results having the significance () since confirming the $\mathrm{H} 9$.

The positive effect of purchase criteria over brand loyalty has also been proved by the results of the study that show the significance of $(B=.124)$ that confirms the H5.

The study measured the direct and indirect effect of advertising spending over the brand loyalty which the prior researches like (Hong Youl Ha) measured in indirect ways. The direct effect of brand loyalty is shown by the statistical result with the significance of $(B=.127)$ that proof the H6 hence shown positive relationship while indirect effect is measured in terms of effect over brand image that is having the significance of (.453) stating the conformance of H7.

This research would be helpful for marketers since it shows not only the effect of the dimensions of brand loyalty on it but also show the effects of variables on each other thus giving the marketers an opportunity to strengthen one variable and it will have dual effect in increasing the brand loyalty by enhancing its other factors.

\section{Limitations and Future Research}

It is important to note that due to limited resources, the existing study is limited to one city of Pakistan and it could not be the demonstrative of the all citizens of Pakistan. Present study includes the very small sample size; the follow up researches may increase the sample size and can collect the data from various major cities of Pakistan. Apart from that the research only measured the brand loyalty towards the only product Samsung cell phones and did not specify the type of the phones (whether they are smart phones or what) so it is not applicable on all classes of phone. Since the survey only questioned about the Samsung phone so the results and finding are only applicable on Samsung not other phones brands. Last but not least the study did not included the price factor and the quality in Pakistan is measured in term of cost so another research would be needed to investigate the effect of price over the brand loyalty. 


\section{MInstitute ${ }_{\text {Mnk }}^{\text {Macrothin }}$}

\section{$\underline{\text { References }}$}

Aaker, D. A. (1991). Managing brand equity: Capitalizing on the value of a brand name. New York: Free Press.

Aaker, D. A. (1996).Measuring brand equity across products and markets. California Management Review, 38(3), 102-120.

Anderson, E. W., Fornell, C., \& Lehmann, D. R. (1994). Customer satisfaction, market share, and profitability: Findings from Sweden. Journal of Marketing, 58(3), 53-66.

Aaker, David A. (1996), "Measuring Brand Equity Across Products and Markets," California Management Review, 38 (Spring), 102-20.

Algesheimer, Rene, Dholakia, Uptal M., Herrmann, Andreas (2005), "The Social Influence of Brand Community; Evidence From European Car Clubs", Journal of Marketing, Vol.69, p.19-34

Anderson C.James\&NarusA.James, (1990), "A Model of Distributor Firm And Manufacturer Firm Working Partnerships", Journal of Marketing Vol.54 (Jaunary 1990), p.42-58

Auh, S., Salisbury, L. C., \& Johnson, M. (2003).Order effects in customer satisfaction modelling. Journal of Marketing Management, 19(3/4), 379-400.

Back, K. J. (2005). The effects of image congruence on customers' brand loyalty in the upper middle-class hotel industry. Journal of Hospitality and Tourism Research, 29(4), 448-467.

Back, K. J., \& Parks, S. C. (2003). A brand loyalty model involving cognitive, affective, and conative brand loyalty and customer satisfaction. Journal of Hospitality and Tourism Research, 27(4), 419-435.

Bandyopadhyay, S., \& Martell, M. (2007). Does attitudinal loyalty influence behavioural loyalty? A theoretical and empirical study. Journal of Retailing and Consumer Services, 14(1), $35-44$.

Baldinger, Allan L. (1990), "Defining and Applying the Brand Equity Concept: Why the Researcher Should Care," Journal of Advertising Research, 30 (June/July), RC2-RC5.

Baldinger, Allan L. and J. Rubinson (1996), "Brand Loyalty: The Link Between Attitude and Behavior," Journal of Advertising Research, 36 (November/December), 22-34.

Bennet, Rebekah, Rundle-TheleSharyn (2002), A Comparison of Attitudinal Loyalty Measurement Approaches, Brand Management, Vol. 9, No.3, January, p.193-209

Bitner, Mary Jo (1990), "Evaluating Service Encounters; The Effects of Physical Surroundings and Employee Responses", Journal of Marketing, Vo.54, April 1990, p.69-82

Bhattacharya C.B. \&SenSankar, (2003), "Consumer-Company Identification: A Framework For Understanding Consumers' Relationships With Companies", Journal of Marketing Vol.67, p.76-88 


\section{MInstitute Macrothink $_{\text {Int }}$}

Ballester-Delgado Elena and Aleman-Munuera Jose, (2001), "Brand Trust In The Context of Consumer Loyalty",European Journal of Marketing 35,11/2, p.1238-1258

Ballester-Delgado Elena and Aleman-Munuera Jose, (2005), "Does Brand Trust Matter To Brand Equity? ",Journal of Product \& Brand Management 14/3 (2005), p.187-196

Baron, R. M., \& Kenny, D. A. (1986). The moderator-mediator variable distinction in social psychological research: Conceptual, strategic and statistical considerations. Journal of Personality and Social Psychology, 51, 1173-1182.

Bart Yakov, Shankar Andnkatesh, Sultan Fateena\&Urban Glen L., (2005), "Are the Driandrs And Role of Online Trust the Same For All Web Sites And Consumers? A Large-Scale Exploratory Empirical Study", Journal of Marketing, 69, p.133-152.

Brady K.Michael\& Jr. J.Joseph Cronin, (2001), "Some New Thoughts On Conceptualizing Perceived Service Quality: A Hierarchical Approach, Journal of Marketing Vol.65 (July 2001), p. 34-39.

BagozziP.Ricard, Warshaw R. Paul, (1990), Trying To Consume, Journal of Consumer Research,Vol.17 (September 1990).

Bloemer, Josee, (1998), "Linking Perceiandd Service Quality And Service Loyalty; A Multi-Dimensional Perspectiand", European Journal of Marketing, Vol.33, 11/12, p.1082-1106

Bigne, J. E., Sanchez, M. L., \& Sanchez, J. (2001). Tourism image, evaluation variables and after purchase behaviour: Inter-relationship. Tourism Management, 22(6), 607-616.

Aaker, David A. (1991), "Managing Brand Equity: Capitalizing on the Value of a Brand Name". New York: The Free Press.

Aaker, David A. (1996), "Measuring Brand Equity Across Products and Markets," California Management Review, 38 (Spring), 102-20.

Algesheimer, Rene, Dholakia, Uptal M., Herrmann, Andreas (2005), "The Social Influence of Brand Community; Evidence From European Car Clubs", Journal of Marketing, Vol.69, p.19-34

Anderson C.James\&NarusA.James, (1990), "A Model of Distributor Firm And Manufacturer Firm Working Partnerships", Journal of Marketing Vol.54 (Jaunary 1990), p.42-58

Baldinger, Allan L. (1990), "Defining and Applying the Brand Equity Concept: Why the Researcher Should Care," Journal of Advertising Research, 30 (June/July), RC2-RC5.

Baldinger, Allan L. and J. Rubinson (1996), "Brand Loyalty: The Link Between Attitude and Behavior," Journal of Advertising Research, 36 (November/December), 22-34.

Bennet, Rebekah, Rundle-TheleSharyn (2002), A Comparison of Attitudinal Loyalty Measurement Approaches, Brand Management, Vol. 9, No.3, January, p.193-209 
Bitner, Mary Jo (1990), "Evaluating Service Encounters; The Effects of Physical Surroundings and Employee Responses", Journal of Marketing, Vo.54, April 1990, p.69-82

Bloemer, Josee, (1998), "Linking Perceiandd Service Quality And Service Loyalty; A Multi-Dimensional Perspectiand",European Journal of Marketing, Vol.33, 11/12, p.1082-1106

Bhattacharya C.B. \&SenSankar, (2003), "Consumer-Company Identification: A Framework For Understanding Consumers' Relationships With Companies", Journal of Marketing Vol.67, p.76-88

Ballester-Delgado Elena and Aleman-Munuera Jose, (2001), "Brand Trust In The Context of Consumer Loyalty", European Journal of Marketing 35,11/2, p.1238-1258

Ballester-Delgado Elena and Aleman-Munuera Jose, (2005), "Does Brand Trust Matter To Brand Equity? ",Journal of Product \& Brand Management 14/3 (2005), p.187-196

Baron, R. M., \& Kenny, D. A. (1986). The moderator-mediator variable distinction in social psychological research: Conceptual, strategic and statistical considerations. Journal of Personality and Social Psychology, 51, 1173-1182.

Bart Yakov, Shankar Andnkatesh, Sultan Fateena\&Urban Glen L., (2005), "Are the DriandrsAnd Role of Online Trust the Same For All Web Sites And Consumers? A Large-Scale Exploratory Empirical Study", Journal of Marketing, 69, p.133-152.

Brady K.Michael\& Jr. J.Joseph Cronin, (2001), "Some New Thoughts On Conceptualizing Perceived Service Quality: A Hierarchical Approach, Journal of Marketing Vol.65 (July 2001), p. 34-39.

BagozziP.Ricard, Warshaw R. Paul, (1990), Trying To Consume, Journal of Consumer Research,Vol.17 (September 1990).

ChaudhuriArjun,HolbrookB.Moris, (2001), "The Chain Of Effects From Brand Trust And Brand Affects To Brand Performance: The Role of Brand Loyalty", Journal of Marketing Vol.65, p.81-93

Che, Hai and Seetharaman, P.B.(Seethu), (2009), "Speed of Replacement": Modeling Brand Loyalty Using Last-Move Data, Journal of Marketing Research, Vol. XLVI, p.494-505

Cannon, Joseph P. And Homburg Christian, (2001), "Buyer-Supplier Relationships And Customer Firm Costs, Journal of Marketing", Vol.65, January-2001, p.29-43

Chiou, Jyh-ShenAndShen Chi-Chung, (2006), "The Effects of Satisfaction, Opportunism, And Asset Specificity On Consumers' Loyalty Intention Toward Internet Portal Sites", International Journal Service Industry Management, 17, 1, p.7-22

Crosby, Lawrence And Stephens, Nancy, (1987), "Effects of Relationship Marketing On Satisfaction, Retention, And Prices In The Life Insurance Industry", Journal of Marketing Research, Vol.iv, Noandmber-1987, p.404-11 


\section{$\triangle$ Macrothink}

Caceres Ruben ChumpitazAndPaparoidamis Nicholas G., (2007), "Service Quality, Relationship Satisfaction, Trust, Commitment And Business-T-Business Loyalty", European Journal of Marketing Vol.41 No. 7/8, 2007 p.836-867

Cannon, Joseph P. And Homburg Christian, (2001), "Buyer-Supplier Relationships And Customer Firm Costs, Journal of Marketing", Vol.65, January-2001, p.29-43

Chiou, Jyh-ShenAndShen Chi-Chung, (2006), "The Effects of Satisfaction, Opportunism, And Asset Specificity On Consumers' Loyalty Intention Toward Internet Portal Sites", International Journal Service Industry Management, 17, 1, p.7-22

Crosby, Lawrence And Stephens, Nancy, (1987), "Effects of Relationship Marketing On Satisfaction, Retention, And Prices In The Life Insurance Industry", Journal of Marketing Research, Vol.iv, Noandmber-1987, p.404-11

Caceres Ruben ChumpitazAndPaparoidamis Nicholas G., (2007), "Service Quality, Relationship Satisfaction, Trust, Commitment And Business-T-Business Loyalty", European Journal of Marketing Vol.41 No. 7/8, 2007 p.836-867

ChaudhuriArjun,HolbrookB.Moris, (2001), "The Chain Of Effects From Brand Trust And Brand Affects To Brand Performance: The Role of Brand Loyalty", Journal of Marketing Vol.65, p.81-93

Che, Hai and Seetharaman, P.B.(Seethu), (2009), "Speed of Replacement": Modeling Brand Loyalty Using Last-Move Data, Journal of Marketing Research, Vol. XLVI, p.494-505

Dixon, Jane, Bridson, Kerrie, Evans, Jody And Morrison, Michael, (2005), "An Alternative Perspection On Relationships, Loyalty And Future Store Choice", In.Rev.ofReatail Distribution And Consumer Research, Vol.15, No.4, 351-374

Dall'olmo, Francesca, AndChernatony, Leslie De, (2000), "The Service Brand As Relationships Builder", British Journal of Management, Vol.11, S.137-150

Duncan, Tom AndMoriarity Sandra, E, (1998), "A Communication-Based Marketing Model for Managing Relationships", Journal of Marketing, Vol.62, April 1998, S.1-13

Dick, Alan S. and KunalBasu (1994), "Customer Loyalty: Toward an Integrated Conceptual Framework," Journal of the Academy of Marketing Science, 22 (Spring), 99-113.

Doney, Patricia M. and Joseph P. Cannon, (1997), "An Examination of the Nature of Trust in Buyer-Seller Relationships," Journal of Marketing, 61 (April), 35-51.

Dixon, Jane, Bridson, Kerrie, Evans, Jody And Morrison, Michael, (2005), "An Alternative Perspection On Relationships, Loyalty And Future Store Choice", In.Rev.ofReatail Distribution And Consumer Research, Vol.15, No.4, 351-374

Dall'olmo, Francesca, AndChernatony, Leslie De, (2000), "The Service Brand As Relationships Builder", British Journal of Management, Vol.11, S.137-150 


\section{Macrothink}

Journal of Sociological Research

ISSN 1948-5468

2014, Vol. 5, No. 1

Duncan, Tom AndMoriarity Sandra, E, (1998), "A Communication-Based Marketing Model for Managing Relationships", Journal of Marketing, Vol.62, April 1998, S.1-13

Dick, Alan S. and KunalBasu (1994), "Customer Loyalty: Toward an Integrated Conceptual Framework," Journal of the Academy of Marketing Science, 22 (Spring), 99-113.

Doney, Patricia M. and Joseph P. Cannon, (1997), "An Examination of the Nature of Trust in Buyer-Seller Relationships," Journal of Marketing, 61 (April), 35-51.

Eagly AH, Chaiken S (1993). The psychology of attitudes. Harcourt College Publishers. Fort Worth.

East R, Hammond K (1996).The erosion of repeat-purchase loyalty.Mar. Let., 7(2): 163-171.

Fullerton Gordon,(2005), "The Impact of Brand Commitment On Loyalty to Retail Service Brands", Canadian Journal of Administratiand Sciences 22(2), 97-110

Fournier Susan \& Mick Glen David, (1999), Rediscoandring Satisfaction, Journal Of Marketing Vol.63 (October 1999),5-23

Fournier Susan \& Mick Glen David, (1999), Rediscoandring Satisfaction, Journal Of Marketing Vol.63 (October 1999),

$5-23$

Fullerton Gordon,(2005), "The Impact of Brand Commitment On Loyalty to Retail Service Brands", Canadian Journal of Administratiand Sciences 22(2), 97-110

Genesh J, Arnold MJ, Reynolds KE (2000). Understanding of customerbase of service providers: An examination of the differences betweenswitchers and stayers. J. Mar., 64(2): 65-87.

González MEA, Comesaña LR, Brea JAF (2007).Assessing touristbehavioural intentions through perceived service quality andcustomer satisfaction. J. Bus. Res., 60: 153-160.

Harman HH (1967). Modern factor analysis.University of Chicago Press.Chicago.Henning-Thurau T (2004). Customer orientation of service employees:its impact on customer satisfaction, commitment, and retention. Int. J.Ser. Ind. Manage., 15(5): 460-478.

Hult GTM, Ketchen D (2001). Does market orientation matter? a test ofthe relationship of positional advantage and performance. Strateg.Manage. J., 22(9): 899-906.

Jaworski B, Kohli A (1991). Supervisory feedback: alternative types andtheir impact on sales people's performance and satisfaction. J. MarRes., 28(2): 190-201.

Kapferer JN (2005). The roots of brand loyalty decline: an internationalcomparison. Ivey Bus. J., 69(4): 1-6.

Keller KL (1998). Strategic brand management.Prentice Hall.Englewood Cliffs. 


\section{Al Macrothink}

Journal of Sociological Research

ISSN 1948-5468

2014, Vol. 5, No. 1

Kennedy KN, Goolsby JR, Arnould EJ (2003). Implementing a customerorientation: extension of theory and application. J. Mar., 67(4): 67-81.

LaBarbera PA, Mazursky D (1983). A longitudinal assessment ofconsumer satisfaction/dissatisfaction: The dynamic aspect of thecognitive process. J. Mar. Res., 20(4): 393-404.

Lee J, Back K (2008). Attendee-based brand equity.Tour. Manage.,29(2): 331-344.

Luo X, Seyedian M (2003). Contextual marketing and customer orientationstrategy for e-commerce: An empirical analysis. Int. J.Electron. Commer., 8(2): 95-118.

Mattila AS, Enz CA (2002). The role of emotion in service encounters. J.Ser. Res., 4(4): 268-277.

McConnell JD (1968). The development of brand loyalty: anexperimental study. J. Mar Res., 5(1): 13-19.

$\mathrm{Na}$ Z, Shim JS (2010). The effects of perceived uncertainty on servicesatisfaction in the Chinese commercial banking industry. Asia-Pac J.Bus., 1(2): 83-106.

Ragunathan, R. and Irwin, J.R. (2001), "Walking the hedonic product treadmill: default contrast

and mood-based assimilation in judgments of predicted happiness with a target product",

Journal of Consumer Research, Vol. 28 No. 3, pp. 355-68.

Rizwan, M., Ahmad, W., Tahir, S., Ali, S., Naz, A., Ain, Q. \& Peerzada, P. (2013) Antecedents of Brand Loyalty: An Empirical Study from Pakistan, International Journal of Research in Commerce, Economics and Management, 3(3), 169-174

Rizwan, M., Riaz, T., Akhter, N., Murtaza, G., Hasnain, M., Hussain, L. \& Rasheed, I. (2013) Antecedents of Brand Loyalty an Empirical Study from Pakistan, International Journal of Research in Computer Applications and Management, 3(3), 165-171

Roest, H. and Pieters, R. (1997), "The nomological net of perceived service quality", InternationalJournal of Service Industry Management, Vol. 8 No. 4, pp. 336-51.

Schweizer, K., Moosbrugger, H. and Schermeller-Engel, K. (2003), "Models for hierarchical structures in differential psychology", Methods of Psychological Research Online, Vol. 8

No. 2, pp. 159-80.

Sirgy, M.J. and Samli, A.C. (1985), "A path analytic model of store loyalty involving self-concept, store image, geographic loyalty, and socioeconomic status", Journal of the Academy ofMarketing Science, Vol. 13 No. 3, pp. 265-91.

Stern, B.L., Bush, R.F. and Hair, J.F. (1977), “The self-image/ store image matching process: an empirical test", Journal of Business, Vol. 50 No. 1, pp. 63-9. 


\section{Al Macrothink}

Journal of Sociological Research

ISSN 1948-5468

2014, Vol. 5, No. 1

Tabachnick, B.G. and Fidell, L.S. (1999), Using Multivariate Statistics, 4th ed., Allyn and Bacon, Boston, MA.Tellis, G.J. (1988), "Advertising exposure, loyalty, and brand purchase: a two-stage model of choice”, Journal of Marketing Research, Vol. 25 No. 2, pp. 134-44.

Tepeci, M. (1999), "Increasing brand loyalty in the hospitality industry", International Journal of Contemporary Hospitality Management, Vol. 11 No. 5, pp. 223-30.

Villarejo-Ramos, A.F. and Sanchez-Franco, M.J. (2005), "The impact of marketing communication and price promotion on brand equity", Journal of Brand Management, Vol. 12 No. 6, pp. 431-44.

Wheatley, J.J. and Chiu, J.S. (1977), "The effects of price, store image, and product and respondent characteristics on perceptions of quality", Journal of Marketing Research, Vol. 14, May, pp. 181-6. Yoo, B., Donthu, N. and Lee, S. (2000), "An examination of selected marketing mix elements and brand equity", Journal of the Academy of Marketing Science, Vol. 28 No. 2, pp. 195-211.

Zeithaml, V., Berry, L.L. and Parasuraman, A. (1996), “The behavioral 